
\title{
25 Research Square \\ Quantifying the impact of severe bushfires on biodiversity to inform conservation
}

\section{Kelsee Baranowski}

Department of Biology, Center for Infectious Disease Dynamics, The Pennsylvania State University, University Park, PA 16802, USA https://orcid.org/0000-0003-4720-1398

\section{Christina Faust}

Department of Biology, Center for Infectious Disease Dynamics, The Pennsylvania State University, University Park, PA 16802, USA https://orcid.org/0000-0002-8824-7424

\section{Peggy Eby}

Centre for Ecosystem Science, University of New South Wales, Sydney, NSW 2052, Australia

Nita Bharti ( $\square$ nita@psu.edu )

Department of Biology, Center for Infectious Disease Dynamics, The Pennsylvania State University, University Park, PA 16802, USA https://orcid.org/0000-0003-1940-7794

\section{Article}

Keywords: mega-fires, forest fragmentation, Pteropus, habitat loss, climate change

Posted Date: June 29th, 2020

DOI: https://doi.org/10.21203/rs.3.rs-36234/v1

License: (c) (1) This work is licensed under a Creative Commons Attribution 4.0 International License. Read Full License 


\section{Abstract}

The unusually severe 2019-2020 Australian bushfire season destroyed large areas of habitat along the southeastern coast. We assess the differences between this fire season and previous ones to understand their impacts and potential recovery. We used thermal satellite data to quantify the extent of eastern Australian bushfires from 2012-2020. During the 2019-2020 anomalous fire season, 134 mega-fires, each over 10,000 ha, burned $62.5 \%$ of the total affected area, including critical forested landscapes. Previous fire seasons were characterized by smaller, scattered fires in mostly non-forested areas. The anomalous fire season had direct negative impacts on wildlife including grey-headed flying foxes, which experienced substantial declines in immediately available foraging forest habitat, particularly key winter resources. We identified important areas for managing wildlife resources and supporting ecosystem health in the coming decades. Our research also identifies key monitoring areas to improve our understanding of ecosystem recovery and resilience in changing fire regimes.

\section{Introduction}

Fire is essential for maintenance of biodiversity across ecosystems globally ${ }^{1}$. Fire-adapted animal and plant species can thrive in nutrient-rich ash post fire ${ }^{2}$ and some are dependent on fire for new generations ${ }^{3}$. Despite the vital role of fires, extensive high-intensity fires can have negative impacts on ecosystem health by reducing biodiversity $4,5,6$ and causing declines in wildlife populations ${ }^{7,8}$. Uncontrolled fires can also damage human health ${ }^{9}$ and property ${ }^{10}$. The negative impacts of fire on ecosystems can be long-lasting ${ }^{11}$ and new fire regimes can delay or prevent the recovery of ecosystems altogether ${ }^{12}$. Climate change-induced heat and drought has extended the length of fire seasons and augmented burnable area across the globe ${ }^{13}$. It is increasingly important to understand the impact of these emerging fire regimes that reduce the resiliency of affected ecosystems to better manage them presently and mitigate future negative outcomes.

Australia is particularly vulnerable to climate-driven changes in fire regimes. While fire occurrence is a product of complex management practices, local conditions, history, and chance $14,15,16$, Australian wildfires, often called bushfires, are tightly linked with local weather conditions and climate oscillations ${ }^{17}$, 18. The forested ecosystems found across Australia, namely Eucalypts (tribe Eucalypteae within Myrtaceae), are fire-adapted and flower quickly following typical fires ${ }^{19}$. However, high intensity fires can damage epicormic growth beyond recovery ${ }^{19}$; more frequent and/or severe fires can prevent recovery of forests and promote domination of alternative ecosystems ${ }^{20}, 21$. Both the intensity and frequency of bushfires is predicted to increase with climate change ${ }^{22}$, raising questions of whether forested ecosystems will be able to persist and support endemic wildlife in shifting fire regimes. In 2019-2020, local weather and climate conditions in eastern Australia gave rise to an unusually dry spring combined with an accumulation of fuels ${ }^{23}, 24$. This created favorable conditions for anomalous, severe, devastating 
bushfires that burned primarily in forested ecosystems and dominated international headlines for months 25

The location and extent of 2019-2020 bushfires lead to initial estimates that one billion animals perished ${ }^{26}$ and that there had been an increased extinction risk for some endemic species ${ }^{27}$, but the true impact of these fires is still under investigation. In the aftermath of typical fires, surviving animal populations decline in the face of higher predation risk and limited resources ${ }^{7,8}$. High intensity fires often lead to steeper declines in species and have a longer-term effect on the landscape ${ }^{28}$. While bats have been found to suffer low direct mortality during fires ${ }^{29,30}$, increasing evidence suggests that the extent and distribution of unburned habitat is key for predicting the post-fire success of surviving animal populations. Not much is known about the consequences of bushfires for nectar- and fruit-dependent flying foxes (Pteropus species) despite their role in vegetation recovery through pollination $31,32,33,34,35$ and dispersal of seeds over long distances during seasonal movements ${ }^{35}$. Without regard to their importance within these ecosystems, these animals were legally culled historically due to their consumption of commercial fruits, nuisance (smell and noise) in urban environments, and fears of the emergence of the zoonotic pathogens they host, including Hendra and Lyssa viruses ${ }^{35}$. One species, the grey-headed flying fox (Pteropus poliocephalus),, is classified as 'Vulnerable' due to $30 \%$ population declines related to habitat loss and human disturbance $36,37,38$. Large fires impact many animal and plant populations, but the responses of vulnerable and endangered populations are particularly critical to understand, especially for preserving biodiversity and maintaining ecosystem health and balance.

There is mounting evidence that the scale and intensity of 2019-2020 fires were a consequence of climate change ${ }^{39}$, suggesting that conservation activities will need to incorporate these events into future planning. The short- and long- term population impacts post-fire on wildlife caused by these fires are yet to be determined. To quantify the recent anomalous fire season (September 2019- March 2020), we used remotely sensed thermal data to compare the extent of burned area and distribution of fires across eastern Australia of the anomalous bushfires (2019-2020) to a previous bushfire season with similar total burned area in the spring and summer of 2012-2013. We then compared the amount of forest cover burned during these fire seasons across the heavily populated states of eastern Australia. Finally, we assessed how these fires impacted the Vulnerable grey-headed flying fox by quantifying burned and remaining foraging habitats. This work prioritizes locations and species of vegetation for urgent surveillance, preservation, and restoration.

\section{Results}

\section{Fire extent between years}

Between 2012 and 2020 in the eastern states of Australia, the total burned area of each annual fire season from September to March ranged from 2.40 million hectares (Mha) in 2015-2016 to 8.48 Mha in 2012-2013 (Figure 1a; Table S2). The area burned in the 2012-2013 fire season was the most similar to 
2019-2020 fire season (5\% less than 2012-2013) and affected more than twice the area burned in most of the intervening years. The 2012-2013 fire season, hereafter known as the previous focal fire season, was used for comparison to the recent 2019-2020 fire season, hereafter referred to as the anomalous fire season. We assessed the similarities and differences in the distribution, extent, and impact of these two fire seasons.

In the previous focal fire season, 67,722 unique contiguous fires burned $8.48 \mathrm{Mha}$, mostly in savannahs and open woodlands with low levels of canopy cover ( $<20 \%$ canopy cover, Figure $2 \mathrm{c}$ ). In contrast, the anomalous fire season burned 8.03 Mha but consisted of only 29,148 individual fires, many burning areas that were an order of magnitude larger than the previous focal fire season (Figure 1). Fire size is a key predictor in the severity of fires and determines the scale of consequences for animal and plant populations.

During the previous focal fire season, individual bushfires burned much smaller areas and were more numerous. Mega-fires $\left(>10,000 \mathrm{ha}^{40}\right)$ only accounted for $17.1 \%$ of the total burned area. During the recent anomalous fire season, the majority (62.5\%) of the burned area was concentrated in a few mega-fires (Figures 1, 2e). The burned area calculations presented here reflect data collection at a spatial resolution of 440 meters, additional calculations at coarser resolutions to account for variation in the size of scan pixels are presented in the SI (Figures S6-S8). Calculations using coarser resolutions lead to much larger estimates of burned areas but show a similar distribution of fire sizes (Table S3, S4, Figures S6-S8).

The anomalous fire season also coincides with greater rainfall deficits in the nine months preceding the peak of the fire season, particularly on the coast between Sydney and Brisbane, and deficits covered a larger spatial extent preceding the anomalous fire year (Figure 2b,d).

\section{Forest fragmentation and impact on refugia after fires}

Due to a combination of anthropogenic pressure and natural disasters, forests are steadily declining annually in eastern Australia (Figure 3a). Remaining forest area (defined with a canopy cover of $>20 \%$ ) has decreased by $3.9 \%$ over the last decade. Forest area covered $12.4 \%$ of land in 2009 , which declined to $11.9 \%$ in 2018 (Figure 3a). Fragmentation accompanied much of this forest cover decline, resulting in an increased abundance of forest patches (Figure 3a). In 2012, there were 28 forest patches that were greater than 100,000 ha in size, each with a high proportion of high-quality core forest habitat, defined as forest area at least $100 \mathrm{~m}$ from a forest edge ${ }^{41}$. These large forest patches accounted for $63.2 \%$ of total forest cover in eastern Australia in 2012. Although many of these patches are in protected areas (Figure S3), these forests had been fragmented and lost core habitat forest by 2018 (Figures 3b, S9).

The impact of fires on forested habitat was drastically different between the previous focal fire season and the anomalous fire season. In the previous focal fire season, the vast majority of total burned area $(77.5 \%)$ was in non-forested areas, whereas in the anomalous fire season, the majority of total burned area $(66.2 \%)$ occurred in forested areas (Figure 2e). The mega- fires that accounted for the majority of the 
burned area occurred primarily in large, contiguous forests in New South Wales. Fires burned entire forest patches of all sizes, as demonstrated by the reduction in total number of forest patches (Figure S10). Fires also effectively broke up large continuous forests and left a greater number of moderately sized forest fragments $>1,000$ ha, reducing the total unburned forest habitat area while increasing the number of patches (Figure 3c).

\section{Fire impacts on grey-headed flying fox habitat}

We quantified burned habitat ${ }^{42}$ from both the previous focal fire season and anomalous fire season in relation to roosts that were recently occupied (FF1 and FF2; Table 1). For each roost, we quantified total foraging habitat and winter habitat within a $50 \mathrm{~km}$ radius to account for maximum foraging distances (average $20-30 \mathrm{~km}$ ) from individual roosts ${ }^{43}, 44$. This area includes $87.5 \%$ of the total extant grey-headed flying fox habitat. Winter habitat, which is a subset of foraging habitat, includes the five most annually reliable and productive nutritional resources during winter resource bottlenecks (Eucalyptus robusta, E. tereticornis, E. siderophloia, Melaleuca quinquenervia, and Banksia integrifolia) ${ }^{42}$.

\section{Table 1. Datasets for assessing fire impacts on flying foxes.}

\begin{tabular}{|c|c|c|c|c|c|}
\hline $\begin{array}{l}\text { Name } \\
\text { of } \\
\text { flying } \\
\text { fox } \\
\text { Dataset }\end{array}$ & Time period & $\begin{array}{l}\text { Criteria for } \\
\text { inclusion }\end{array}$ & $\begin{array}{l}\text { Number of } \\
\text { roosts } \\
\text { meeting } \\
\text { inclusion } \\
\text { criteria }\end{array}$ & $\begin{array}{l}\text { Geographic } \\
\text { extent }\end{array}$ & $\begin{array}{l}\text { Downstream } \\
\text { analysis }\end{array}$ \\
\hline FF1 & $\begin{array}{l}09 / 2007- \\
09 / 2012\end{array}$ & $\begin{array}{l}\text { Presence of } \\
\text { flying foxes at } \\
\text { roost }\end{array}$ & 248 & $\begin{array}{l}\text { New South } \\
\text { Wales and } \\
\text { Queensland }\end{array}$ & $\begin{array}{l}\text { Roost-level habitat } \\
\text { quantification for } \\
2012-2013 \\
\text { (including burned } \\
\text { area) }\end{array}$ \\
\hline FF2 & $\begin{array}{l}09 / 2015- \\
09 / 2019\end{array}$ & $\begin{array}{l}\text { Presence of } \\
\text { flying foxes at } \\
\text { roost }\end{array}$ & 324 & $\begin{array}{l}\text { New South } \\
\text { Wales and } \\
\text { Queensland }\end{array}$ & $\begin{array}{l}\text { Roost-level habitat } \\
\text { quantification for } \\
2019-2020 \\
\text { (including burned } \\
\text { area) }\end{array}$ \\
\hline FF3 & $\begin{array}{l}09 / 2011-03 / \\
2013 \text { (excluding } \\
09 / 2012- \\
03 / 2013 \text { fire } \\
\text { season) }\end{array}$ & $\begin{array}{l}\text { Minimum of } 6 \\
\text { observations } \\
\text { (presence or } \\
\text { absence) }\end{array}$ & 92 & $\begin{array}{l}\text { Queensland } \\
\text { only }\end{array}$ & $\begin{array}{l}\text { Generalized logistic } \\
\text { regression model } \\
\text { (outcome variable is } \\
\text { presence/absence) }\end{array}$ \\
\hline
\end{tabular}

In the previous focal fire season, the amount of foraging habitat burned within range of FF1 roosts ranged from 24 to 26,854 ha (Figure S11, S12). Only $3.7 \%$ of the total grey-headed flying fox habitat across southeastern Queensland and New South Wales was burned. The median habitat burned within an individual roost's foraging radius was slightly lower, $2.89 \%$; the most affected roost experienced 
$19.86 \%$ of its foraging habitat burned. At each roost, the percentage of total foraging habitat burned was highly correlated with the percentage of winter habitat burned, but winter habitat covers a much smaller spatial extent (Figure 4c-h).

The anomalous 2019-2020 fire season burned 2.8 Mha (33.7\%)of total foraging habitat, drastically reducing resources immediately available for grey-headed flying foxes in parts of their range (Figure $4 \mathrm{~b}$ ). Of the 324 FF2 roosts, 62 had greater than one-fourth of their total foraging habitat (single roost maximum $63.7 \%$, median: $4.58 \%$ ) burned by the anomalous fire season. The greatest amount of foraging habitat burned at a single roost $(313,189 \mathrm{ha})$ in the anomalous fire season, was similar to the total habitat burned across all of New South Wales and Queensland in the previous focal fire year $(318,484$ ha). Winter habitat was also significantly impacted in the 2019-2020 fires; a single roost experienced $68.5 \%$ (74,475 ha) of its winter foraging habitat burned (Figure $4 \mathrm{i})$.

A greater proportion of all winter diet species burned in the anomalous fire season (single species maximum: $35.5 \%$, median: $25.4 \%$ ) compared to the previous focal fire season (single species maximum: $6.1 \%$, median: $4.8 \%$ ) (Figure S13). Changes in winter foraging habitats have cascading implications on population persistence and the scale of these declines is particularly important. Even Melaleuca quinquenervia, a critical winter resource that is found in fire refugia (swamps, floodplains, and riparian zones), experienced burning across $13.8 \%$ of its distribution in $2019-2020$, compared to $4.1 \%$ in $2012-$ 2013 (Figure S13).

Grey-headed flying fox roost occupancy before and after the previous focal fire season

We used a longitudinal survey of presence and abundance of flying fox species at roosts in the seasons before and after the previous focal fire season to determine fire impacts on grey-headed flying fox occupancy ${ }^{45}$. The presence of grey-headed flying foxes at the roosts identified in FF3 was significantly affected by total unburned area of winter habitat within a $50 \mathrm{~km}$ foraging radius, meteorological season, co-occupation of black flying foxes, and geographic location.

The best fit mixed effects logistic regression showed that roosts with more abundant unburned winter habitat were more likely to be occupied by grey-headed flying foxes at any time of the year (adjusted odds ratio (aOR): $5.16,95 \%$ confidence interval $(\mathrm{Cl}): 2.01,13.30)$. Additionally, grey-headed flying foxes were more likely to be observed at roosts during winter (aOR: 1.72, 95\% Cl: 1.14, 2.61) and spring (aOR: 2.20 , $95 \% \mathrm{Cl}: 1.43,3.39$ ) compared with autumn (summer was not significantly different). Further, the presence of black flying foxes at a roost site was also significantly associated with occupancy of grey-headed flying foxes (aOR: $98.8,95 \% \mathrm{Cl}: 53.6,182.0$ ). Finally, latitudes located further north were less likely to be occupied by grey-headed flying foxes (aOR: $0.55,95 \% \mathrm{Cl}$ : 033,0.93). Direct fire metrics (i.e. distance from roost to burned area, total area burned in foraging radius, and habitat burned) were not included in the best fit logistic regression.

\section{Discussion}


The anomalous 2019-2020 bushfires were unprecedented in their size, impact on forest ecosystems, and destruction of wildlife habitat in eastern Australia. These analyses highlight the drastic reductions in foraging habitats, including key winter resources, for the already threatened grey-headed flying fox. Monitoring wildlife population responses, quantifying fire intensity, and understanding the resilience of vegetation to these extreme fires will be essential for designing management and mitigation strategies in the coming months and years as fire regimes shift with global climate change ${ }^{46}$.

\section{Anomalous fire characteristics and impact on forest habitats}

The anomalous size and location of fires in 2019-2020 destroyed extensive areas of key forest habitat 25. Mega-fires, defined as anything over 10,000 ha, are associated with higher intensity burns, longer recovery periods, major alterations of canopy structure, and higher direct and indirect mortality ${ }^{47}$. There were 67 mega-fires across eastern Australia in the anomalous fire season, with the largest fire burning almost 1.6 Mha. Wildlife can often persist or relocate in smaller fires, but these larger fires are devastating in the short- and long-term for many species ${ }^{5,47}$. Here we highlight the significant amount of total and winter foraging habitat of grey-headed flying foxes that burned in the 2019-2020 fire season. Flowering in Eucalypts commences earlier when fire intensity is low and the full depth of bark is not scorched ${ }^{28,48}$. Epicormic resprouting along branches starts almost immediately after fire and reduces the time to flowering ${ }^{19}$. However, the extensive drought (Figure 2d) and extreme heat conditions preceding the fires 23 likely reduced or delayed flowering of diet species in the short-term ${ }^{49}$. We expect a net decrease in floral resources for flying foxes following fires, particularly from larger, high-intensity fires.

Reductions in winter foraging habitats have been associated with increased adult mortality, low reproductive rates, young with low birth weight, and birth defects in grey-headed flying foxes ${ }^{36}$. Our analyses demonstrate that occupation of roosts is highly correlated with adjacent winter foraging resources. We propose the 2019-2020 fires will have significant population impacts on grey-headed flying foxes through substantial reduction in habitat and feeding resources at specific roosts. Although there are no other studies of flying fox responses to fires, studies of other bat species have shown that fires impact populations through the alteration of foraging and roosting habitat $50,51,52$, and other Australian bats (non-Pteropus) have been shown to decrease activity in local areas in the months following bushfires and up to one-year after major fires ${ }^{29,52}$. The anomalous season of 2019-2020 bushfires significantly impacted foraging resources for grey-headed flying foxes, which will alter their feeding behavior, and in turn, could delay recovery of Eucalypts that benefit from their pollination.

\section{Threats to wildlife and humans from anomalous fires}

The eastern Australian forests, including Eucalypt dominated stands, are an important global biodiversity hotspot ${ }^{53}$. The ongoing anthropogenic loss of forest habitat throughout eastern Australia in the decades preceding these fires puts additional constraints on the post-fire recovery of wildlife populations. While forest fragmentation impacts populations variably, a decline in total amount of habitat negatively impacts many wildlife taxa $54,55,56$. Grey-headed flying foxes could theoretically respond to $60 \%$ forage 
habitat burning, as observed in New South Wales during the anomalous fires, by migrating to unaffected (or less affected) roosts and foraging areas. But unaffected roosts are surrounded by highly fragmented habitat limited in extent and frequently overlapping with black flying foxes, which are resource competitors. Alternative roosts are also located in urban environments that are largely unaffected by annual fire seasons. These areas contain a variety of mostly anthropogenic food resources, which that are lower-quality than their native food sources but more reliably available and may influence roost occupancy ${ }^{57}$. Movement to alternative roosts with minimal burned habitat or urban sites may be further limited by nutritional status of individuals ${ }^{58}$. Extreme drought and few options for suitable alternative habitats put populations of grey-headed flying foxes in a precarious position to recover from these extreme events. Monitoring timing of resource flowering, population movements and roost colonization will be essential for informing local conservation efforts to ensure their persistence, recovery of native Eucalypt forests, and safety for human populations.

Beyond wildlife populations, large wildfires also have direct and indirect negative consequences for human populations. Loss of life and property is most frequently associated with large fires $9,59,60$. Initial estimates from the 2019-2020 fires resulted in 417 excess deaths, 3151 excess hospitalizations and 1305 emergency room visits ${ }^{61}$. There are also indirect negative human health impacts - the increase in air particulates damages respiratory tissues and increases susceptibility to respiratory infections, such as seasonal influenza. In damaging lung tissue, the 2019-2020 fires may have also increased susceptibility to infection with pandemic SARS-CoV-2, or increased the likelihood of severe symptoms with infection.

\section{Future of vulnerable species and ecosystem health under changing fire regimes}

The loss of habitat during fires may also drive grey-headed flying foxes and black flying foxes into urban environments, increasing the risk for spillover, or cross-species transmission, of pathogenic viruses ${ }^{62}$. For example, these Australian flying foxes carry and transmit Lyssa virus and Hendra virus are examples of viruses, which can sicken or kill humans and animals ${ }^{62}$. Previous studies have proposed preserving and restoring critical resources to draw flying foxes out of human settlements to reduce risk of viral transmission ${ }^{63}$. Implementation of these proposed management strategies is even more critical now to help restore the large loss of native vegetation and prevent pathogenic viruses from transmitting across species ${ }^{63}$. Areas of unburned winter habitat near heavily impacted roosts identified here (blue, Figure 4ch) need to be monitored closely and preserved, as these are now lifelines for displaced populations. Loss of this vulnerable vegetation will have direct negative impacts on biodiversity, particularly for birds, mammals, and invertebrates that rely on Eucalypts for food, refuge and breeding sites ${ }^{64}$. Restoration of forests generally should focus on increasing overall area while limiting negative impacts of edge-effects on populations by joining existing fragmented patches ${ }^{65}$. Strategic restoration of foraging habitat may offer some resilience to mitigate impacts of bushfires on flying fox populations and other wildlife that are dependent on native forests. 
Increases in the size and frequency of large fires have been documented in North America 66, 67, 68 . Climate change is expected to increase extreme fire conditions in Australia 22 and burnable area in Europe 69 . Prolonged drought and higher temperatures are leading to the drying out of new landscapes and burning of ecosystems not adapted to fires ${ }^{70}$. Empirical evidence from the US also demonstrates that, with climate change, post-fire weather conditions show reduced capacity for forest recovery ${ }^{71}$. The recent large bushfires affected Eucalypt forest communities that are resilient to high severity wildfire ${ }^{72}$, but less is known about their response to high frequency, high severity fires. Increased fire frequency is expected to promote shrub recruitment and shift ecosystems away from tree- dominated landscapes in Australian alpine environments ${ }^{17}$ and enable encroachment of wildfire into fire refugia ${ }^{73}$. Species in typical fire refugia, including many in the genus Melaleuca, were much more likely to burn in the 2019-2020 anomalous fire season than the previous focal fire season. The encroachment of wildfire into less fireresilient vegetation communities increases as extreme drought dries fuels below critical thresholds within fire refugia ${ }^{73}$. The recovery of vegetation from these fires in already fragile ecosystems will depend on the severity and frequency of fire and the postfire climate. Postfire climate can promote recovery or facilitate additional fires that might push these systems beyond resilience ${ }^{40}$.

\section{Conclusion}

Using remotely sensed active fire data, we rapidly mapped and quantified estimates of burned area in the anomalous 2019-2020 bushfire season in eastern Australia. Compared to a previous bushfire season (2012-2013), we show that the fires were much larger and more concentrated across the landscape, burning much larger swaths of forest than previous years. This study highlights the substantial impact on foraging habitat of grey-headed flying foxes and identifies the most affected roosts, which will be important to monitor in the coming months and years. We also identify key areas of unburned habitat that need to be preserved to limit loss of biodiversity. The severity of the 2019-2020 fire season has been linked to climate change and such seasons are expected to become more frequent in the coming years. Understanding the response of vegetation and wildlife to these extreme events will improve our ability to help build resilience into these systems as climate change alters the frequency and intensity of fires in Australia and other ecosystems globally.

\section{Methods}

This study focuses on the eastern Australian states of Queensland (QLD), New South Wales (NSW), Australian Capital Territory (ACT) and Victoria (VIC) (Figure 2a). This region of Australia has the nation's highest human population density, highest biodiversity and largest tracts of remaining forest habitats ${ }^{53}$.

\section{Acquisition and processing of spatial fire and forest data}


We retrieved fire incidence data from NASA's Fire Information for Resource Management System (FIRMS) Visible Infrared Imaging Radiometer Suite (VIIRS) Active Fire and Thermal Anomalies for September 1 to March 1 of each fire season from 2012 to $2020^{74}$. For example, we used VIIRS data from September 1 , 2012 to March 1, 2013 to quantify burned area in the previous focal fire season. VIIRS Active Fire and Thermal Anomaly data are collected every 12 hours and anomalies are based on a dual gain high saturation temperature mid-infrared channel, band $\mathrm{M} 13$, and single gain thermal infrared channel, band $\mathrm{M} 15^{75}$ (see SI). An algorithm classifies pixels as thermal anomalies or "hotspots" 75 . We converted fire anomaly points to a raster to generalize burned area at the highest spatial resolution of the FIRMS data in Australia, 440 meters. We also describe analysis at a coarser spatial resolution to address variation in scan and pixel size in the SI. We additionally calculated total burned area with the incorporation of small 'unburned' gaps enclosed in the raster to prevent underestimating burned area missed by satellite passes (SI). We used the resulting raster of burned area in each year to summarize key metrics: including total burned area, number of unique fires (as number of unconnected polygons), proportion of area burned by 'moderately sized' fires (>100 ha), and proportion of area burned by 'mega-'fires (>10,000 ha).

Spatial and temporal data on forest cover comes from a global dataset of $30 \mathrm{~m}$ resolution tree canopy cover estimates derived from LANDSAT imagery ${ }^{76}$. For the purposes of this analysis, we define forested areas as tree cover of $20 \%$ or more in a 30m x 30m pixel. Tree cover in 2012 and 2018 was calculated based on gain and loss products provided in the Global Forest Change dataset v1.6 (see SI for details; original dataset in ${ }^{76}$ ). We used $30 \mathrm{~m}$ resolution data from $2009-2018$ to examine forest fragmentation and forest loss in this period. Forest patch sizes, edges, and core-area indices were calculated for forest patches (considered when pixel edges, but not vertices, are adjacent). To measure the degree of fragmentation in forests across the region, we estimated core area by creating a $100 \mathrm{~m}$ inner buffer for each forest patch $>100,000$ ha in 2012 and compared these metrics to the largest remnant forest patch in 2018 (2018 was used as a best approximation for forest cover in 2019 at the start of the fire season). We then resampled the forest area using maximum combined area selection to $440 \mathrm{~m}$ resolution to compare with fire extent, again using a $20 \%$ cut-off for forest and non-forest pixels (see $\mathrm{SI}$ ).

\section{Grey-headed flying fox roost responses to fire and habitat loss}

To examine how wildfires may impact wildlife populations, we utilized longitudinal monitoring data of flying fox (Pteropus species) roost sites in the states of Queensland and New South Wales. Roost counts are conducted approximately quarterly, location and occupancy data (count estimates in Queensland and presence/absence in New South Wales) are publicly available through the National Flying Fox Monitoring Program ${ }^{45}$. The flying fox roost surveys were subset into three datasets to quantify the area of habitat burned from both the previous focal fire season (FF1) and the anomalous fire season (FF2) fire years and to evaluate 2012-2013 fire season responses in southeast Queensland (FF3) (Table 1). 
For each roost, we quantified total foraging habitat, winter habitat, and burned area within a $50 \mathrm{~km}$ radius to account for maximum foraging distances (average $20-30 \mathrm{~km}$ ) from individual roosts ${ }^{43,44}$. We define winter habitat as areas that contain at least one of five species (Eucalyptus robusta, E. tereticornis, E. siderophloia, Melaleuca quinquenervia, and Banksia integrifolia).. While there are 13 grey-headed flying fox diet species that can flower during winter, the selected five species represent the most annually reliable and productive species during resource bottlenecks in winter months ${ }^{42}$. To evaluate differences between fire seasons, we only quantified habitat around roosts that were occupied in the preceding five years - from 2007-2012 (for 2012-2013 fires: FF1) and 2014-2019 (for 2019-2020 fires: FF2). A generalized additive model with a beta distribution and logit link function was used to summarize proportion burned winter habitat by latitude and year for occupied roosts. Models were created and evaluated in R version 3.6.1 with the package $\operatorname{mgcv}^{77}$.

To explore evidence of fire impacts on roost occupancy, we focused on modelling roost dynamics in the four seasons preceding and following the 2012-2013 wildfire season (from September 2011 to March 2014) (Figure S4). Observations recorded during the fire season (September 2012-March 2013) were excluded. Presence and absence of grey-headed flying foxes were fit with logistic mixed effects models, with roost identities were included as random effects to account for temporal autocorrelation. The dataset was truncated to only include camps that had a minimum of four observations in pre-and postfire periods, resulting in 92 roosts in Queensland, referred to here as dataset FF3 (Table 1). Univariate and multivariate logistic regressions were evaluated with several predictor variables described below, including: presence of another species of flying fox, area of grey-headed flying fox habitat, area of winter habitat, distance to closest burned area, proportion of habitat burned, proportion of winter habitat burned, latitude, and season (Tables S1, S4). Logistic mixed effects models were created and evaluated in R version 3.6.1 using $/ \mathrm{me} 4^{78,79}$.

\section{Declarations}

\section{Author Contributions}

K.B., C.L.F., and N.B. designed the research; K.B. analyzed fire extent; C.L.F analyzed forest fragmentation and impact of fire; K.B. and C.L.F analyzed impact of fire on grey-headed flying fox habitat; all authors contributed to writing the paper.

\section{Data availability statement}

Data analyzed in this study are available in public repositories (see Methods) and the scripts to analyze these data will be made available on GitHub (https://github.com/cfaustus/aus20192020_fires_ff currently private, will be made public).

\section{Funding}


This work was funded by the National Science Foundation (grant no. CNH-L: 1716698), the Defense Advanced Research Projects Agency PREEMPT program (Cooperative Agreement \#D18AC00031), and the Huck Institutes of the Life Sciences at The Pennsylvania State University. The content of the information does not necessarily reflect the position or the policy of the U.S. government, and no official endorsement should be inferred.

\section{References}

1.Bowman DM, et al. Fire in the Earth system. Science 324, 481-484 (2009).

2.Bradstock R, Davies I, Price O, Cary G. Effects of climate change on bushfire threats to biodiversity, ecosystem processes and people in the Sydney region. Final report to the New South Wales department of environment and climate change: climate change impacts and adaptation research project 50831, 65 (2008).

3.Krawchuk MA, Moritz MA, Parisien M-A, Van Dorn J, Hayhoe K. Global pyrogeography: the current and future distribution of wildfire. PloS one 4, (2009).

4.Pastro LA, Dickman CR, Letnic M. Burning for biodiversity or burning biodiversity? Prescribed burn vs. wildfire impacts on plants, lizards, and mammals. Ecological Applications 21, 3238-3253 (2011).

5.Berry LE, Lindenmayer DB, Driscoll DA. Large unburnt areas, not small unburnt patches, are needed to conserve avian diversity in fire-prone landscapes. Journal of Applied Ecology 52, 486-495 (2015).

6.Lindenmayer DB, et al. Complex responses of birds to landscape-level fire extent, fire severity and environmental drivers. Diversity and Distributions 20, 467-477 (2014).

7.Lawes MJ, Murphy BP, Fisher A, Woinarski JC, Edwards AC, Russell-Smith J. Small mammals decline with increasing fire extent in northern Australia: evidence from long-term monitoring in Kakadu National Park. International Journal of Wildland Fire 24, 712-722 (2015).

8.Leahy $\mathrm{L}$, et al. Amplified predation after fire suppresses rodent populations in Australia's tropical savannas. Wildlife Research 42, 705-716 (2016).

9.Liu JC, Pereira G, Uhl SA, Bravo MA, Bell ML. A systematic review of the physical health impacts from non-occupational exposure to wildfire smoke. Environmental Research 136, 120-132 (2015).

10.Blanchi R, Lucas C, Leonard J, Finkele K. Meteorological conditions and wildfire-related houseloss in Australia. International Journal of Wildland Fire 19, 914-926 (2010).

11.Bowd EJ, Lindenmayer DB, Banks SC, Blair DP. Logging and fire regimes alter plant communities. Ecological Applications 28, 826-841 (2018). 
12.Gill AM, Stephens SL, Cary GJ. The worldwide "wildfire" problem. Ecological Applications 23, 438-454 (2013).

13.Jolly WM, et al. Climate-induced variations in global wildfire danger from 1979 to 2013. Nature communications 6, 1-11 (2015).

14.Pausas JG, Keeley JE. A burning story: the role of fire in the history of life. Bioscience 59, 593-601 (2009).

15.Oliveras I, Bell T. An analysis of the Australian literature on prescribed burning. Journal of forestry 106, 31-37 (2008).

16.Gill AM. Underpinnings of fire management for biodiversity conservation in reserves. Department of Sustainability and Environment: Melbourne, (2008).

17.Camac JS, Williams RJ, Wahren $\mathrm{CH}$, Hoffmann AA, Vesk PA. Climatic warming strengthens a positive feedback between alpine shrubs and fire. Global Change Biology 23, 3249-3258 (2017).

18.Cai W, Cowan T, Raupach M. Positive Indian Ocean dipole events precondition southeast Australia bushfires. Geophysical Research Letters 36, (2009).

19.Bennett LT, Bruce MJ, MacHunter J, Kohout M, Tanase MA, Aponte C. Mortality and recruitment of firetolerant eucalypts as influenced by wildfire severity and recent prescribed fire. Forest Ecology and Management 380, 107-117 (2016).

20.Fairman TA, Nitschke CR, Bennett LT. Too much, too soon? A review of the effects of increasing wildfire frequency on tree mortality and regeneration in temperate eucalypt forests. International Journal of Wildland Fire 25, 831-848 (2016).

21.Bowman DM, Murphy BP, Neyland DL, Williamson GJ, Prior LD. Abrupt fire regime change may cause landscape-wide loss of mature obligate seeder forests. Global Change Biology 20, 1008-1015 (2014).

22.Fasullo J, Otto-Bliesner B, Stevenson S. ENSO's changing influence on temperature, precipitation, and wildfire in a warming climate. Geophysical Research Letters 45, 9216-9225 (2018).

23.Nolan RH, et al. Causes and consequences of eastern Australia's 2019-20 season of mega-fires. Global Change Biology, (2020).

24.Lindenmayer DB, Kooyman RM, Taylor C, Ward M, Watson JEM. Recent Australian wildfires made worse by logging and associated forest management. Nature Ecology \& Evolution, (2020).

25.Boer MM, Resco de Dios V, Bradstock RA. Unprecedented burn area of Australian mega forest fires. Nature Climate Change 10,171-172 (2020). 
26.Cox L. A billion animals: some of the species most at risk from Australia's bushfire crisis. In: The Guardian) (2020).

27.Lam SS, Waugh C, Peng W, Sonne C. Wildfire puts koalas at risk of extinction. Science 367,750 (2020).

28.Denham AJ, Vincent BE, Clarke PJ, Auld TD. Responses of tree species to a severe fire indicate major structural change to Eucalyptus-Callitris forests. Plant ecology 217, 617-629 (2016).

29.Law B, Doty A, Chidel M, Brassil T. Bat activity before and after a severe wildfire in Pilliga forests: Resilience influenced by fire extent and landscape mobility? Austral Ecology 43, 706-718 (2018).

30.Buchalski MR, Fontaine JB, Heady III PA, Hayes JP, Frick WF. Bat response to differing fire severity in mixed-conifer forest California, USA. PloS one 8, (2013).

31.Eby P. Biology and Management of Pteropus in New South Wales. Species Report. NSW National Parks and Wildlife Service, Hurstville, (1995).

32.Eby P. An analysis of diet specialization in frugivorous Pteropus poliocephalus (Megachiroptera) in Australian subtropical rainforest. Australian Journal of Ecology 23, 443-456 (1998).

33.Hall LS, Richards G. Flying foxes: fruit and blossom bats of Australia. UNSW Press (2000).

34.McConkey KR, Drake DR. Flying foxes cease to function as seed dispersers long before they become rare. Ecology 87, 271-276 (2006).

35.Roberts BJ, Catterall CP, Eby P, Kanowski J. Long-distance and frequent movements of the flying-fox Pteropus poliocephalus: implications for management. PloS one 7, e42532-e42532 (2012).

36.Mcllwee A, Martin L. On the intrinsic capacity for increase of Australian flying-foxes (Pteropus spp., Megachiroptera). Australian Zoologist 32, 76-100 (2002).

37.Tidemann CR, Nelson JE. Life expectancy, causes of death and movements of the grey-headed flyingfox (Pteropus poliocephalus) inferred from banding. Acta Chiropterologica 13, 419-429 (2011).

38.Dickman C, Fleming M. Pest, or passenger pigeon? The New South Wales Scientific Committee's assessment of the status of the grey-headed flying-fox. Managing the grey-headed flying-fox as a threatened species in NSW Mosman, NSW: Royal Zoological Society of NSW, 20-28 (2002).

39.van Oldenborgh GJ, et al. Attribution of the Australian bushfire risk to anthropogenic climate change. Nat Hazards Earth Syst Sci Discuss In Review, (2020).

40.Adams MA. Mega-fires, tipping points and ecosystem services: Managing forests and woodlands in an uncertain future. Forest Ecology and Management 294, 250-261 (2013). 
41. Haddad NM, et al. Habitat fragmentation and its lasting impact on Earth's ecosystems. Science Advances 1, e1500052 (2015).

42.Eby P, Law B. Ranking the feeding habitat of grey-headed flying foxes for conservation management. Department of Environment and Climate Change (NSW), Sydney, (2008).

43.Eby P. Seasonal movements of grey-headed flying-foxes, Pteropus poliocephalus (Chiroptera: Pteropodidae), from two maternity camps in northern New South Wales. Wildlife Research 18, 547-559 (1991).

44.Tidemann CR, Vardon MJ, Loughland RA, Brocklehurst PJ. Dry season camps of flying-foxes (Pteropus spp.) in Kakadu World Heritage Area, north Australia. Journal of Zoology 247, 155-163 (1999).

45.Westcott DA, McKeown A, Murphy HT, Fletcher CS. A monitoring method for the grey-headed flying-fox, Pteropus poliocephalus. CSIRO published Guidelines, (2011).

46.Moritz MA, et al. Learning to coexist with wildfire. Nature 515, 58-66 (2014).

47.Stephens SL, et al. Temperate and boreal forest mega-fires: characteristics and challenges. Frontiers in Ecology and the Environment 12, 115-122 (2014).

48.Gill AM. Eucalypts and fires: interdependent or independent. Eucalypt ecology: individuals to ecosystems, 151-167 (1997).

49.Law BS, Anderson J. Roost preferences and foraging ranges of the eastern forest bat Vespadelus pumilus under two disturbance histories in northern New South Wales, Australia. Austral Ecology 25, 352-367 (2000).

50.Blakey RV, Webb EB, Kesler DC, Siegel RB, Corcoran D, Johnson M. Bats in a changing landscape: Linking occupancy and traits of a diverse montane bat community to fire regime. Ecology and Evolution 9, 5324-5337 (2019).

51.Perry RW. A review of fire effects on bats and bat habitat in the eastern oaks region. In: Proceedings of the 4th Fire in Eastern Oak Forests Conference (ed Dey DCS, Michael C.; Clark, Stacy L.; Schweitzer, Callie J.). Department of Agriculture, Forest Service, Northern Research Station (2011).

52.Kunz TH, Lumsden LF, Fenton M. Ecology of cavity and foliage roosting bats. Bat Ecology 1, 3-89 (2003).

53.Williams K, et al. Forests of East Australia: The 35th Biodiversity Hotspot. In: Biodiversity Hotspots: Distribution and Protection of Conservation Priority Areas (eds Zachos F, Habel JC). Springer (2011).

54.Watling $\mathrm{Jl}$, et al. Support for the habitat amount hypothesis from a global synthesis of species density studies. Ecology letters 23, 674-681 (2020). 
55.Fahrig L. Ecological Responses to Habitat Fragmentation Per Se. Annual Review of Ecology, Evolution, and Systematics 48, 1-23 (2017).

56.Ocampo-Peñuela N, Garcia-Ulloa J, Kornecki I, Philipson CD, Ghazoul J. Impacts of Four Decades of Forest Loss on Vertebrate Functional Habitat on Borneo. Frontiers in Forests and Global Change 3, (2020).

57.Paez DJ, et al. Conditions affecting the timing and magnitude of Hendra virus shedding across pteropodid bat populations in Australia. Epidemiology \& Infection 145, 3143-3153 (2017).

58.Voigt CC, Phelps KL, Aguirre LF, Corrie Schoeman M, Vanitharani J, Zubaid A. Bats and Buildings: The Conservation of Synanthropic Bats. In: Bats in the Anthropocene: Conservation of Bats in a Changing World (eds Voigt CC, Kingston T). Springer International Publishing (2016).

59.Dennekamp M, Abramson MJ. The effects of bushfire smoke on respiratory health. Respirology 16, 198-209 (2011).

60.Leibel S. Increase in Pediatric Respiratory Visits associated with Wildfires in San Diego County. Journal of Allergy and Clinical Immunology 143, AB23 (2019).

61.Borchers Arriagada N, Palmer AJ, Bowman DM, Morgan GG, Jalaludin BB, Johnston FH. Unprecedented smoke-related health burden associated with the 2019-20 bushfires in eastern Australia. Medical Journal of Australia, (2020).

62.Plowright RK, et al. Urban habituation, ecological connectivity and epidemic dampening: the emergence of Hendra virus from flying foxes Pteropus spp.). Proceedings of the Royal Society B: Biological Sciences 278, 3703-3712 (2011).

63.Plowright RK, et al. Ecological dynamics of emerging bat virus spillover. Proceedings of the Royal Society B: Biological Sciences 282, 20142124 (2015).

64.Bennett AF. Eucalypts, wildlife and nature conservation: from individual trees to landscape patterns. Proceedings of the Royal Society of Victoria 128, 71-86 (2016).

65.Bradshaw CJ. Little left to lose: deforestation and forest degradation in Australia since European colonization. Journal of Plant Ecology 5, 109-120 (2012).

66.Westerling AL, Hidalgo HG, Cayan DR, Swetnam TW. Warming and earlier spring increase western US forest wildfire activity. Science 313, 940-943 (2006).

67.Barbero R, Abatzoglou JT, Larkin NK, Kolden CA, Stocks B. Climate change presents increased potential for very large fires in the contiguous United States. International Journal of Wildland Fire 24, 892-899 (2015). 
68.Gillett N, Weaver A, Zwiers F, Flannigan M. Detecting the effect of climate change on Canadian forest fires. Geophysical Research Letters 31, (2004).

69.Turco $\mathrm{M}$, et al. Exacerbated fires in Mediterranean Europe due to anthropogenic warming projected with non-stationary climate-fire models. Nature communications 9, 1-9 (2018).

70.Staver AC, et al. Thinner bark increases sensitivity of wetter Amazonian tropical forests to fire. Ecology letters 23, 99-106 (2020).

71.Stevens-Rumann CS, Morgan P. Tree regeneration following wildfires in the western US: a review. Fire Ecology 15, 15 (2019).

72.Collins L. Eucalypt forests dominated by epicormic resprouters are resilient to repeated canopy fires. Journal of Ecology 108, 310-324 (2020).

73.Collins L, Bennett AF, Leonard SW, Penman TD. Wildfire refugia in forests: Severe fire weather and drought mute the influence of topography and fuel age. Global Change Biology 25, 3829-3843 (2019).

74.LANCE FIRMS. NRT VIIRS 375 m Active Fire product VNP14IMGT. (ed (ESDIS) NsESDaIS). NASA (2020).

75.Schroeder W, Oliva P, Giglio L, Csiszar IA. The New VIIRS $375 \mathrm{~m}$ active fire detection data product: Algorithm description and initial assessment. Remote Sensing of Environment 143, 85-96 (2014).

76. Hansen MC, et al. High-resolution global maps of 21 st-century forest cover change. Science 342, 850853 (2013).

77.Wood S. Fast stable restricted maximum likelihood and marginal likelihood estimation of semiparametric generalized linear models. Journal of the Royal Statistical Society (B) 73, 3-36 (2011).

78.Bates D, Mächler M, Bolker B, Walker S. Fitting linear mixed-effects models using Ime4. J Stat Softw $67,1-48$ (2015).

79.R Core Team. R: A Language and Environment for Statistical Computing.). R Foundation for Statistical Computing, (2019).

\section{Figures}


a)

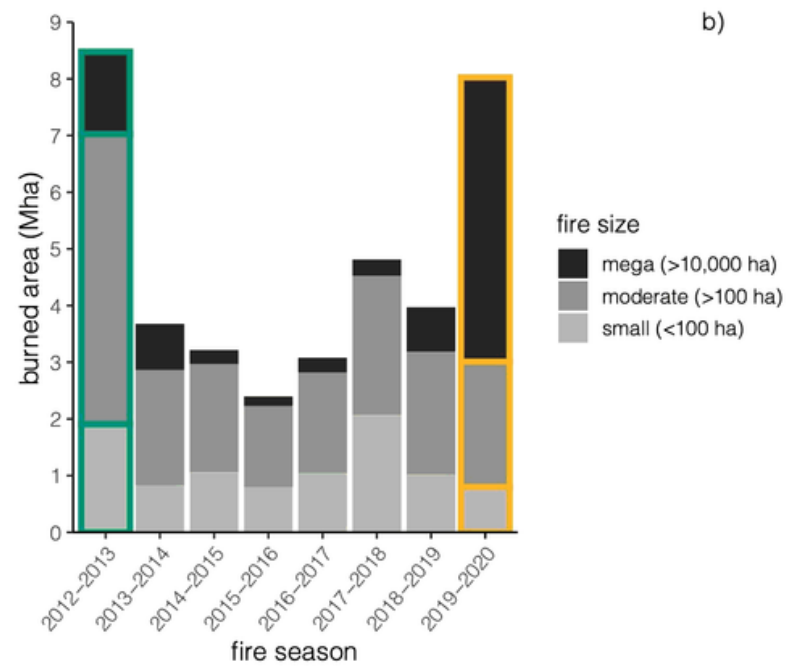

b)

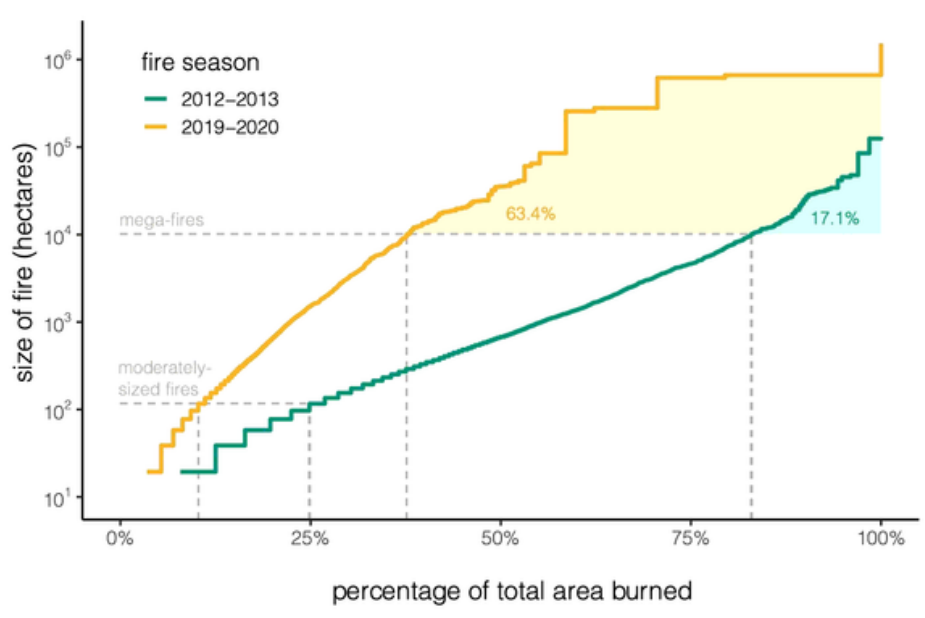

\section{Figure 1}

Burned area and distribution of fire sizes from 2012-2020. a) Burned area in eastern Australia between September and March for years between 2012 and 2020. b) Cumulative burned area by sizes of unique contiguous fires for previous focal and anomalous fire seasons. The distribution of fire sizes showed much larger fires in the 2019-2020 anomalous fire season compared to the previous focal fire season (2012-2013), and the majority of burned area (63.4\%) was within mega- fires (>10,000 ha) as denoted by the shaded area. 


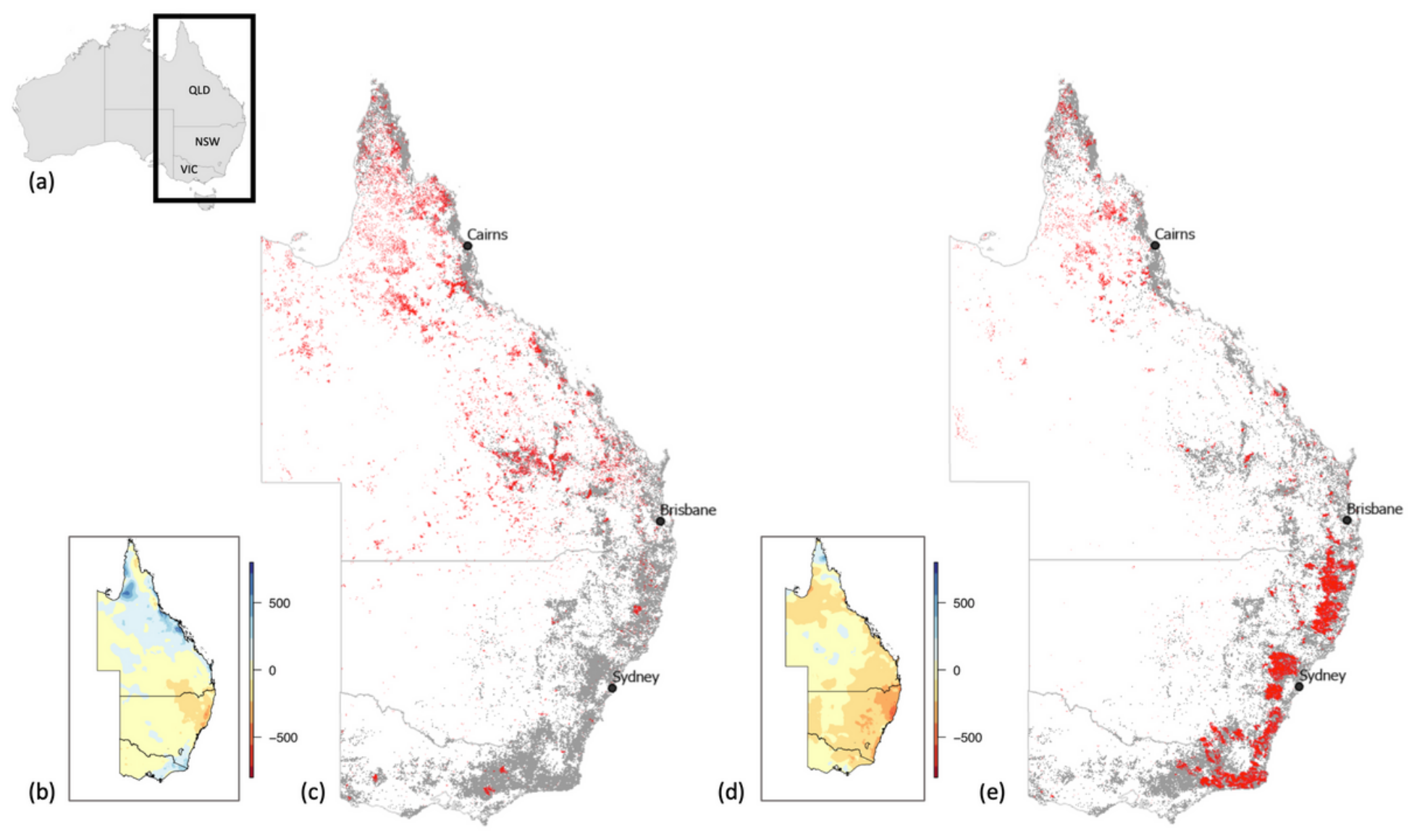

Figure 2

Extent of forest cover and burned areas in eastern Australian with associated rainfall deficits in focal fire seasons (2012-2013 \& 2019-2020). (a) The eastern region of Australia, the states of Queensland (QLD), New South Wales (NSW), Australian Capital Territory (within NSW), and Victoria (VIC). (b,d) 9-month rainfall deficits (March - November) in millimeter $(\mathrm{mm})$ differences from average cumulative rainfall over 30 years calculated for 2012 (b) and 2019 (d). Fire extent (red) in the previous focal fire season (c, 20122013) and the anomalous fire season (e, 2019-2020) overlaid on forest cover ( $>20 \%$ canopy cover per pixel shaded in grey) from the respective years.

(a)

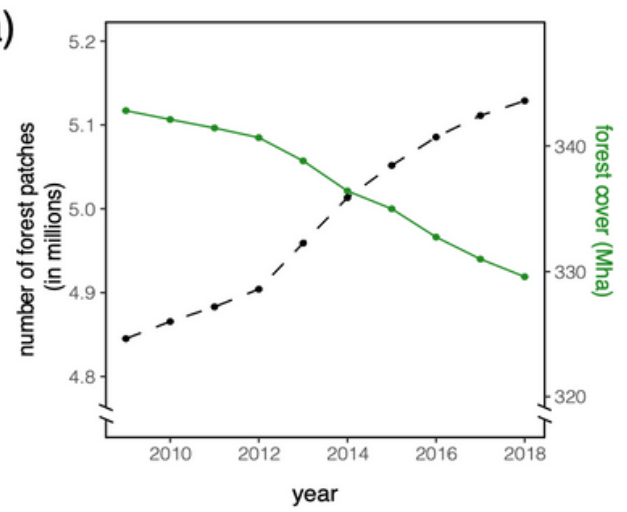

(b)

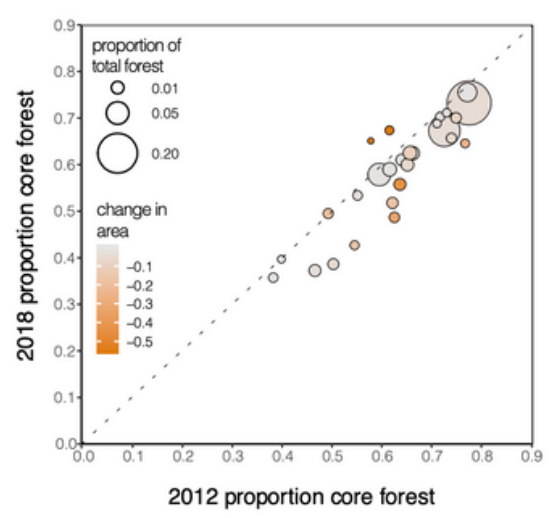

(c)

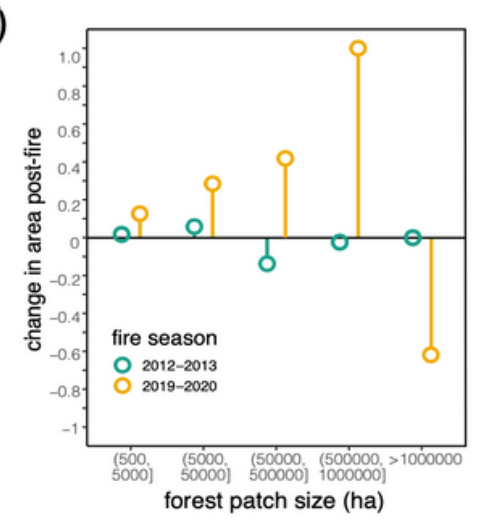

Figure 3 
Forest loss and fragmentation in eastern Australia. (a) The total area of forest cover ( $>20 \%$ canopy cover per $30 \mathrm{~m}$ pixel) has declined over the past decade concomitantly with an increase in the number of noncontiguous forest patches. (b) The 28 contiguous forest patches that were greater than 100,000 ha in 2012 have all declined in area (up to $52 \%$ area was lost via fragmentation or deforestation). Many of these patches also experienced a decrease in the proportion of core habitat (>100m from forest edge). (c) In the anomalous fire season, fire reduced the area of the largest patches of forest, resulting in an increase in number and extent of moderately sized forest fragments in the short term.

(a)

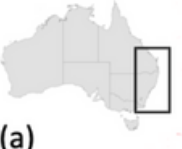

(b)
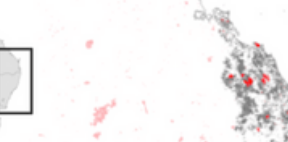

c)

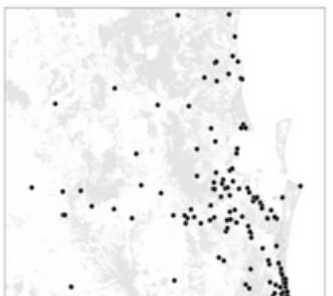

d)

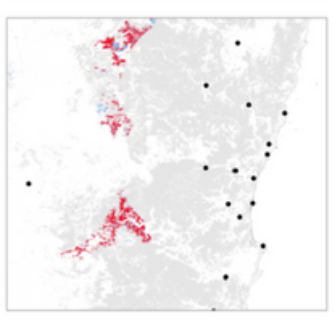

(g)
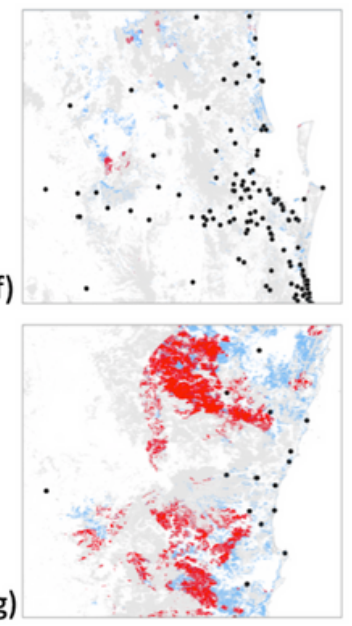

(e)

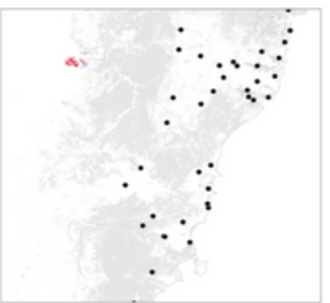

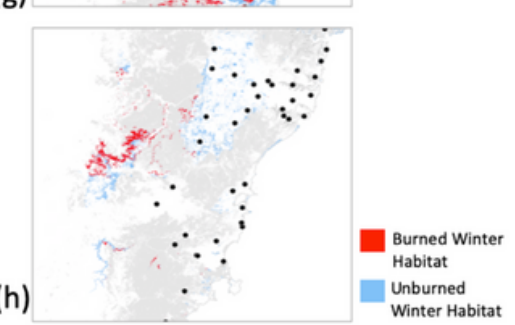

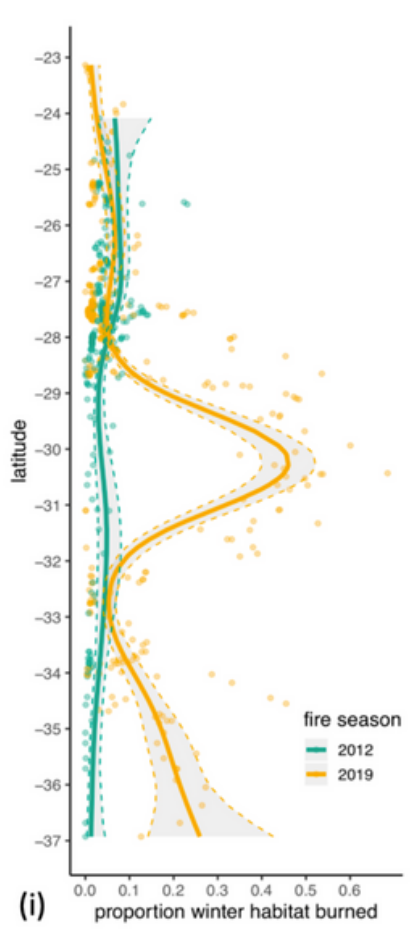

\section{Figure 4}

Extent of 2019-2020 anomalous fire season in flying fox habitats (a) Area of interest, grey-headed flying fox habitat in Queensland and New South Wales is indicated on the map of Australia. (b) Recently occupied roosts in 2019-2020 show burned flying fox habitat within foraging radii indicated in dark red. Light red indicates burned habitat outside the foraging range of roosts. Areas of interest in boxes are shown in winter habitat in panels c-h. Panels (show roosts in black points and all available winter habitat outside (c-e) and inside (f-h) roost foraging radii. Light grey highlights total foraging habitat, whereas red indicates burned winter habitat and blue indicates unburned winter habitat. (i) The proportion of burned winter habitat within foraging radii for each roost is shown in individual points and a GAM is fit to year and latitude to explain $48.1 \%$ of the variation in the proportion of winter habitat burned. Smoothing terms for latitude for each year were significant (2012: 5.931, $p<0.001 ; 2019: 8.505, p<0.001)$. The proportion of winter habitat burned was overall significantly higher in 2019 compared to 2012 (est: $0.398, p<0.001$ ).

\section{Supplementary Files}


This is a list of supplementary files associated with this preprint. Click to download.

- mssfiresffsi202000616cleanv3.docx 